\title{
Cisplatin sensitivity is enhanced in non-small cell lung cancer cells by regulating epithelial- mesenchymal transition through inhibition of eukaryotic translation initiation factor $5 \mathrm{~A} 2$
}

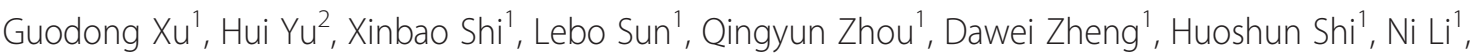
Xianning Zhang ${ }^{3}$ and Guofeng Shao ${ }^{1 *}$

\begin{abstract}
Background: Epithelial-mesenchymal transition (EMT) has been believed to be related with chemotherapy resistance in non-small cell lung cancer (NSCLC). Recent studies have suggested elF5A-2 may function as a proliferation-related oncogene in tumorigenic processes.

Methods: We used cell viability assays, western blotting, immunofluorescence, transwell-matrigel invasion assay, wound-healing assay combined with GC7 (a novel elF5A-2 inhibitor) treatment or siRNA interference to investigate the role of elF5A-2 playing in NSCLC chemotherapy.

Results: We found low concentrations of GC7 have little effect on NSCLC viability, but could enhance cisplatin cytotoxicity in NSCLC cells. GC7 also could reverse mesenchymal phenotype in NCI-H1299 and prevented A549 cells undergoing EMT after TGF- $\beta 1$ inducement. elF5A-2 knockdown resulted in EMT inhibition.

Conclusion: Our data indicated GC7 enhances cisplatin cytotoxicity and prevents the EMT in NSCLC cells by inhibiting elF5A-2.

Keywords: N1-guanyl-1, 7-diaminoheptane (GC7), Eukaryotic translation initiation factor 5A2 (elF5A-2), Epithelialmesenchymal transition (EMT), Cisplatin, Non-small cell lung cancer (NSCLC)
\end{abstract}

\section{Background}

Lung cancer is the leading cause of cancer deaths worldwide with non-small cell lung cancer (NSCLC) accounting for approximately $80 \%$ of all lung cancer diagnoses [1]. Although surgery is the first choice of treatment, chemotherapy is necessary in most cases in order to improve the therapeutic effect; however, despite many novel chemotherapy regimens and molecular targeted therapies, its pathogenesis is yet to be fully understood, and the prognosis remains poor [2-4].

Epithelial-mesenchymal transition (EMT) is a complex, reversible process which induces epithelial cells to

\footnotetext{
* Correspondence: guofengshaolihuili@163.com

'Department of Thoracic \& Cardiovascular Surgery, Lihuili Hospital, Ningbo Medical Center, Affiliated Hospital of Medical School of Ningbo University, NO 57 Xingning Road, Ningbo 315041, China

Full list of author information is available at the end of the article
}

transform to mesenchymal phenotype [5]. These lead to a loss of epithelial characteristics including cell-cell junctions, polarity and epithelial markers, e.g., E-cadherin; and a gain of mesenchymal properties, including stronger migration and invasion capabilities [6] and mesenchymal markers, e.g., vimentin and fibronectin [7]. Although many reports have demonstrated that EMT is involved in drug resistance in NSCLC [8-12], the mechanism is unclear; as such, determining an effective method to inhibit EMT in NSCLC could significantly improve treatment regimes.

Eukaryotic initiation factor (eIF5A) is the the only cellular protein that contains the unusual amino acid hypusine [Ne-(4-amino-2-hydroxybutyl) lysine].It has two isoforms: eIF5A-1 and eIF5A-2. Study demonstrated that accumulating evidence links eIF5A to cell proliferation, cancer progression, invasiveness, metastasis and poor clinical prognosis and the post-translational 
modifications of eIF-5A could be a suitable target for the potentiation of the activity of anti-cancer agents $[13,14]$. eIF5A-2 is located on chromosome 3q26, a region frequently amplified in several types of tumors [15]. It is essential for maintaining cell proliferation [16,17] and inhibition of eIF5A-2 has been shown to suppress cell proliferation in many tumors $[18,19]$. As a result, it has been suggested that eIF5A-2 may function as a proliferationrelated oncogene in tumorigenic processes [20].

Several studies have found that N1-guanyl-1,7-diaminoheptane (GC7) suppresses tumor cell proliferation by inhibiting eIF5A-2 [21,22]. In this study, we aimed to investigate the chemotherapeutic effect of GC7 in NSCLC and determine whether eIF5A-2 mediates EMT and increases chemosensitivity in NSCLC controls.

\section{Methods}

\section{Cell lines and cell culture}

The human NSCLC cell lines, A549 and NCI-H1299, were purchased from the American Type Culture Collection (ATCC; Manassas, VA, USA) and stored following ATCC guidelines. All cells were cultured in Roswell Park Memorial Institute (RPMI) 1640 medium (Invitrogen, Carlsbad, CA, USA) supplemented with $10 \%$ fetal bovine serum (FBS; Gibco, Carlsbad, CA, USA) and 1\% penicillin-streptomycin (Sigma-Aldrich, St. Louis, MO, USA). The cells were maintained at $37^{\circ} \mathrm{C}$ in a humidified atmosphere of $5 \% \mathrm{CO}_{2}$.

\section{elF5A-2 siRNA transfection}

NSCLC cells were transfected with eIF5A-2 siRNA $(10 \mu \mathrm{mol} / \mathrm{mL}$; Santa Cruz Biotechnology, Dallas, TX, USA) or negative control siRNA (Invitrogen) using Lipofectamine 2000 (Invitrogen) according to the manufacturer's instructions. The transfection medium was replaced with culture medium $6 \mathrm{~h}$ after transfection. All subsequent experiments were performed $24 \mathrm{~h}$ after transfection and repeated in triplicate.

\section{CCK-8 cell viability assay}

A Cell Counting Kit-8 (CCK8; Dojindo, Kumamoto, Japan) was used to measure relative cell viability after treatment. NSCLC cells $\left(5 \times 10^{3}\right.$ cells/well $)$ were seeded into 96-well plates and cultured for $24 \mathrm{~h}$. The culture medium was replaced by medium containing the required concentrations of cisplatin or cisplatin combined with GC7, and the cells were incubated for $48 \mathrm{~h}$. CCK-8 solution $(10 \mu \mathrm{L} /$ well $)$ was added, the cells were incubated for a further $4 \mathrm{~h}$, and absorbance was measured at $450 \mathrm{~nm}$ using an MRX II microplate reader (Dynex Technologies, Chantilly, VA, USA). Relative cell viability was calculated as a percentage of untreated controls.

\section{Western blot analysis}

The cells were washed twice in ice-cold phosphate buffer solution (PBS) and resuspended in $100 \mu \mathrm{L}$ cell lysis buffer (Cell Signaling, Danvers, MA, USA) with protease inhibitors (Sigma-Aldrich). The protein concentrations were quantified using a BCA Protein Kit (Thermo Fisher, Rockford, IL, USA). Cell lysates (40 $\mu \mathrm{g} /$ lane) were separated by $10 \%$ SDS-PAGE, transferred to polyvinyl diflouride (PVDF) membranes (Millipore, Billerica, MA, USA) and blocked with Tris-buffered saline (TBS) containing $0.1 \%$ Tween 20 (TBST) and $5 \%$ bovine serum albumin (BSA). The membranes were incubated with antiE-cadherin, anti-Vimentin (Biovision, Milpitas, CA, USA) or anti-eIF5A-2 (Proteintech, Chicago, IL, USA) antibodies $(1: 1000)$ at $4{ }^{\circ} \mathrm{C}$ overnight, washed three times with TBST and then incubated with the appropriate HRP-conjugated secondary antibodies for $1 \mathrm{~h}$ at room temperature. The protein bands were developed by chemiluminescence (GE Healthcare, Piscataway, NJ, USA) and visualized by autoradiography on X-Ray films (Kodak, Rochester, NY, USA). Band densities were estimated using Image-Pro Plus v. 6.0 software (Media Cybernetics, Bethesda, MD, USA) and protein levels were normalized to GAPDH.

\section{Immunofluorescence}

Cells were washed with ice-cold PBS, fixed in 4\% paraformaldehyde for $30 \mathrm{~min}$ followed by incubation with $3 \%$ $\mathrm{H}_{2} \mathrm{O}_{2}$ for $15 \mathrm{~min}$ at $37^{\circ} \mathrm{C}$ and blocked in fetal calf serum for a further $15 \mathrm{~min}$. After incubation with anti-E-cadherin, anti-vimentin or anti-eIF5A-2 antibodies $(1: 1,000)$ overnight at $4^{\circ} \mathrm{C}$, the cells were washed with ice-cold $\mathrm{PBS}$ and incubated for $1 \mathrm{~h}$ at room temperature with the appropriate secondary antibodies (1:2000; GE Healthcare): goat anti-mouse FITC-conjugated secondary antibody (E-cadherin) or goat anti-mouse Cy5-conjugated secondary antibody (vimentin). Nuclei were stained with 4,6-diamidino-2-phenylindole (DAPI; Sigma-Aldrich) and the cells were observed by fluorescence confocal microscopy (Olympus, Japan).

\section{Wound-healing assay}

Cells were seeded into six-well plates at a density of $2 \times 10^{5}$ cells/well and cultured with RPMI-1640 medium containing $10 \% \mathrm{FBS}$ overnight at $37^{\circ} \mathrm{C}$ in a humidified atmosphere of $5 \% \mathrm{CO}_{2}$, after which, the medium was changed to RPMI-1640 without FBS and the cells were cultured for a further $24 \mathrm{~h}$ until $>90 \%$ confluence. The cells were harvested by scraping the adherent cells using a plastic $100 \mu \mathrm{L}$ tip. After transfection with eIF5A-2 siRNA $(10 \mu \mathrm{mol} / \mathrm{mL})$ or treatment with N1-guanyl-1,7diaminoheptane $(\mathrm{GC7} ; 20 \mu \mathrm{M})$ for $6 \mathrm{~h}$, the cells were treated with transforming growth factor- $\beta 1$ (TGF- $\beta 1$ ) at a concentration of $10 \mathrm{ng} / \mathrm{mL}$ for $24 \mathrm{~h}$ at $37^{\circ} \mathrm{C}$ in a 
humidified atmosphere of $5 \% \mathrm{CO}_{2}$. Micrographs were taken using an inverted phase contrast microscope (Olympus; magnification, $40 \times$ ) at $0 \mathrm{~h}$ and $24 \mathrm{~h}$. The ratio of the remaining wound area relative to the initial wound area was calculated and the wound area was quantified using Image-Pro Plus v. 6.0 software.

\section{Transwell-matrigel invasion assay}

After transfection with eIF5A-2 siRNA $(10 \mu \mathrm{mol} / \mathrm{mL})$ or treatment with GC7 $(20 \mu \mathrm{M})$ for $6 \mathrm{~h}$, the cells were treated with TGF- $\beta 1(10 \mathrm{ng} / \mathrm{mL})$ for $48 \mathrm{~h}$. The cells were seeded at a density of $5 \times 10^{4}$ cells/well in the upper chamber of a Transwell 24-insert plate with RPMI-1640 medium. The upper chambers were coated with Matrigel (BD Biosciences, San Jose, CA, USA) and the lower chamber contained RPMI-1640 plus 10\% FBS medium. After $24 \mathrm{~h}$, the bottom of the inserts were fixed in methanol for $10 \mathrm{~min}$ and stained with hematoxylin and eosin (H\&E). The cells that had invaded to the lower surface were measured using an inverted phase contrast microscope (Olympus; magnification, 40x) and photographed.

\section{Statistical analyses}

Data were analyzed using GraphPad Prism 5 software (GraphPad, San Diego, CA, USA) using one-way analysis of variance (ANOVA) followed by Tukey post-hoc test. Results are presented as mean \pm SEM; $P<0.05$ was considered statistically significant.

\section{Results}

Low concentrations of GC7 had little cytotoxicity against NSCLC cells

Western blot analysis was used to determine eIF5A-2 protein expression in A549 and NCI-H1299 cells. The results showed that eIF5A-2 was expressed in the control cells of both cell lines; however expression was higher in NCIH1299 cells compared to A549 cells (Figure 1A). In order to test the cytotoxicity of GC7 in A549 and NCI-H1299 NSCLC cell lines CCK-8 cell viability assays were performed. The results showed that GC7 had almost no effect on A549 cell viability between 0 and $20 \mu \mathrm{M}$, and NCIH1299 cell viability was well when GC7 concentrations were less than $30 \mu \mathrm{M}$, indicating that GC7 had little cytotoxicity against NSCLC cells at low concentrations (Figure 1B,C). Conversely, at GC7 concentrations exceeding $30 \mu \mathrm{M}$ in A549 cells or exceeding $40 \mu \mathrm{M}$ in NCI-H1299 cells, cell viability was significantly inhibited (Figure 1B,C). Some studies have reported that low concentrations of GC7 $(10 \mu \mathrm{M})$ could inhibit the hypusination of eIF5A2 effectively in some tumor cells $[15,19]$. In this case, the $20 \mu \mathrm{M}$ concentration GC7, which has been showed had little cytotoxicity against NSCLC cells but could inhibit the eIF5A2 activation, was chosen for further co-treatments with cisplatin.

\section{GC7 enhanced cisplatin sensitivity of mesenchymal NSCLC cells; epithelial NSCLC cells showed greatest sensitivity to cisplatin}

CCK- 8 assays were carried out to assess the dosedependence of A549 (epithelial phenotype) and NCI-H1299 (mesenchymal phenotype) cell viability to cisplatin treatment. The results found that increasing doses of cisplatin reduced cell viability in both cell lines (Figure $2 \mathrm{~A}$ ): the $\mathrm{IC}_{50}$ values at $72 \mathrm{~h}$ were $3.069 \mu \mathrm{g} / \mathrm{mL}(2.735-3.402 \mu \mathrm{g} / \mathrm{mL})$ and $7.140 \mu \mathrm{g} / \mathrm{mL}(6.432-7.848 \mu \mathrm{g} / \mathrm{mL})$ in A549 and NCIH1299 cells, respectively (Table 1), showing that A549 cells exhibited higher sensitivity to cisplatin than NCIH1299 cells. When cisplatin was combined with GC7 treatment $(20 \mu \mathrm{M})$, cisplatin sensitivity increased in both cell lines compared to cisplatin treatment alone: $\mathrm{IC}_{50}$ values at $72 \mathrm{~h}$ decreased to $4.454 \mu \mathrm{g} / \mathrm{mL}(3.848-$ $5.060 \mu \mathrm{g} / \mathrm{mL} ; P<0.0001$ ) in NCI-H1299 (Figure 2B) and $2.360 \mu \mathrm{g} / \mathrm{mL}(2.098-2.622 \mu \mathrm{g} / \mathrm{mL} ; P<0.01)$ in $\mathrm{A} 549$ cells (Figure 2C, In Additional file 1), indicating that GC7 increased cisplatin sensitivity most markedly in NCI-H1299 cells.

The difference between phenotypes was examined by western blotting and immunofluorescence to detect expression of E-cadherin (epithelial) and vimentin (mesenchymal) EMT markers in both NSCLC cell lines. The

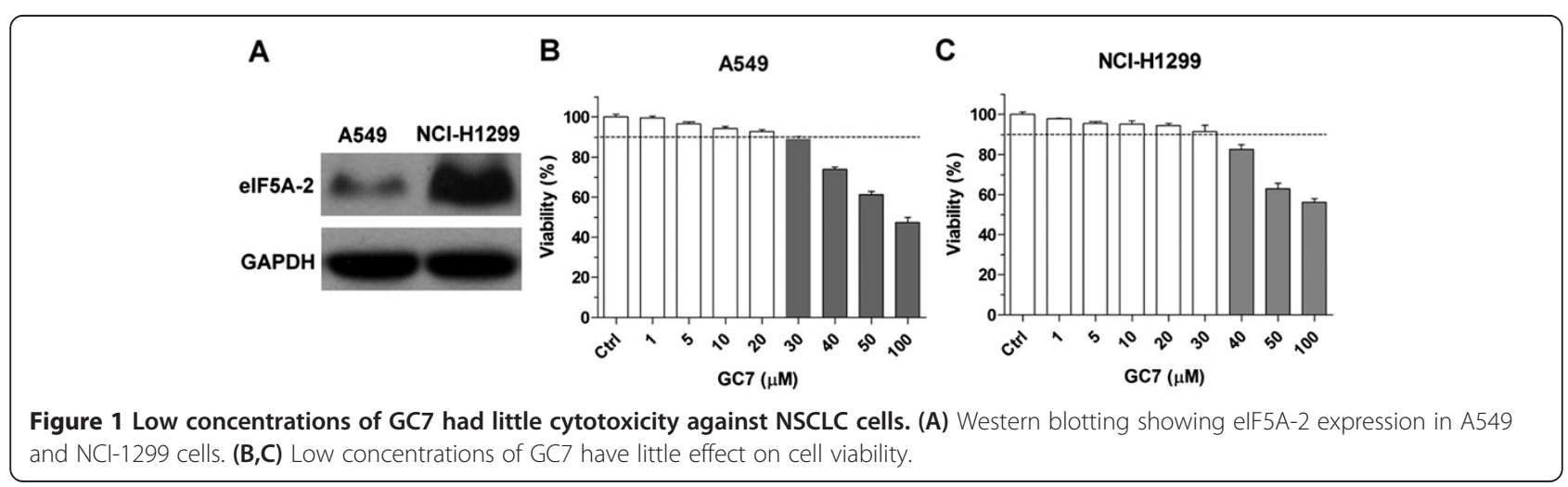




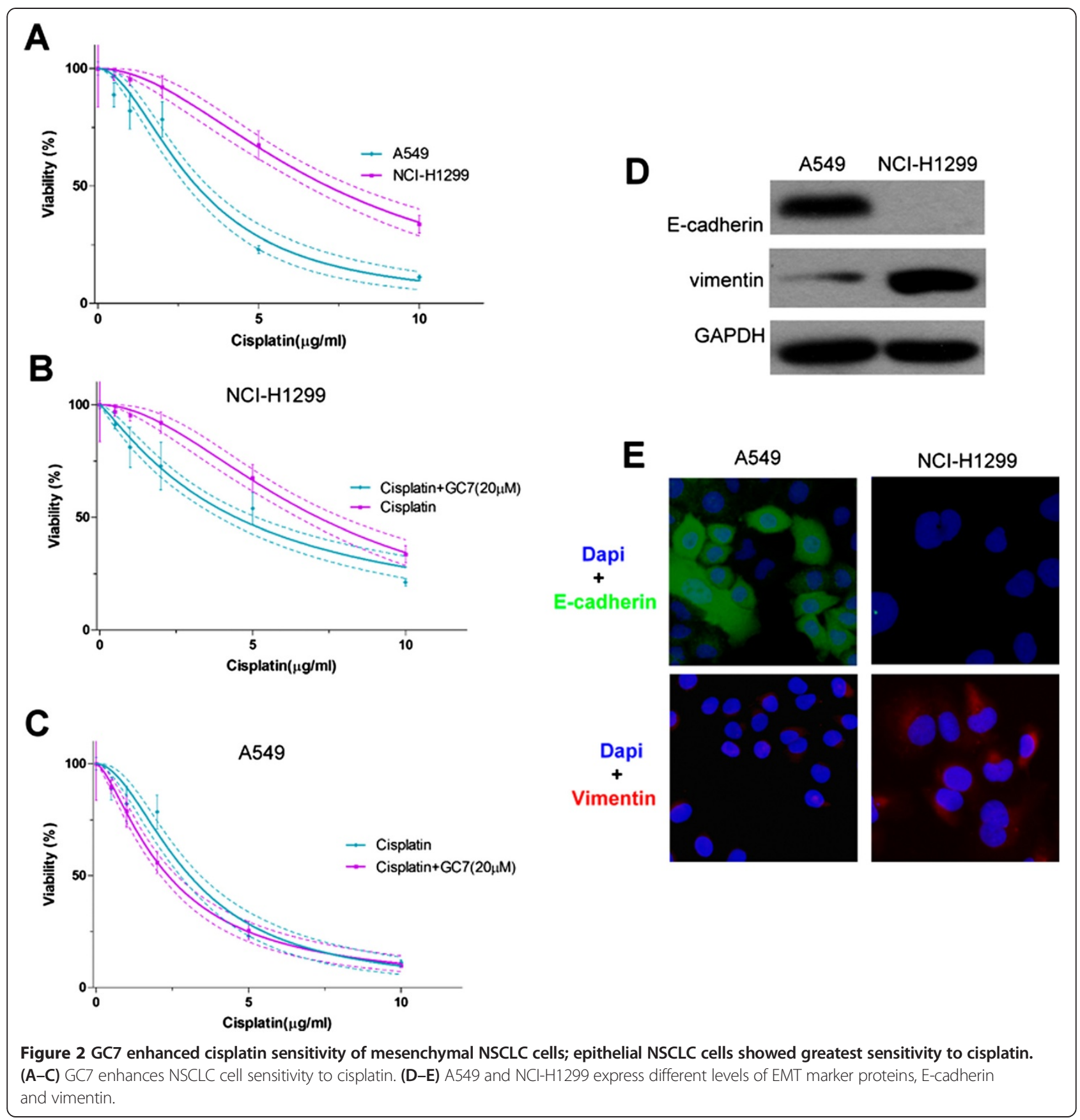

Table 1 IC 50 values for cisplatin in NSCLC cell lines with or without GC7 treatment

\begin{tabular}{|c|c|c|}
\hline \multirow{2}{*}{$\begin{array}{l}\text { NSCLC } \\
\text { cell line }\end{array}$} & \multicolumn{2}{|l|}{$\mathrm{IC}_{50}(\mu \mathrm{g} / \mathrm{mL})^{\Lambda}$} \\
\hline & Cisplatin & Cisplatin + GC7 $(20 \mu \mathrm{M})$ \\
\hline A549 & $3.069(2.735-3.402)$ & $2.360(2.098-2.622)^{* *}$ \\
\hline $\mathrm{NCl}-\mathrm{H} 1299$ & $7.140(6.432-7.848)$ & $4.454(3.848-5.060)^{* * * *}$ \\
\hline
\end{tabular}

${ }_{* *} \mathrm{I}_{50}$ concentrations of cisplatin $[\mu \mathrm{g} / \mathrm{mL}$; mean $(95 \% \mathrm{Cl})]$.

${ }^{* *} P<0.05$ vs. cisplatin alone.

${ }^{* * * * *} P<0.0001$ vs. cisplatin alone. results showed that A549 cells, which were more sensitive to cisplatin, showed higher expression of the epithelial marker E-cadherin, but no expression of the mesenchymal marker vimentin. In contrast, NCI-H1299 showed higher expression of the mesenchymal marker vimentin, but no expression of the epithelial marker E-cadherin (Figure 2D,E).

GC7 enhanced cisplatin sensitivity in NSCLC cells via inhibition of elF5A-2

GC7 can inhibit the activity of eIF5A-2 (In Additional file 2). In order to discover the mechanism by which 


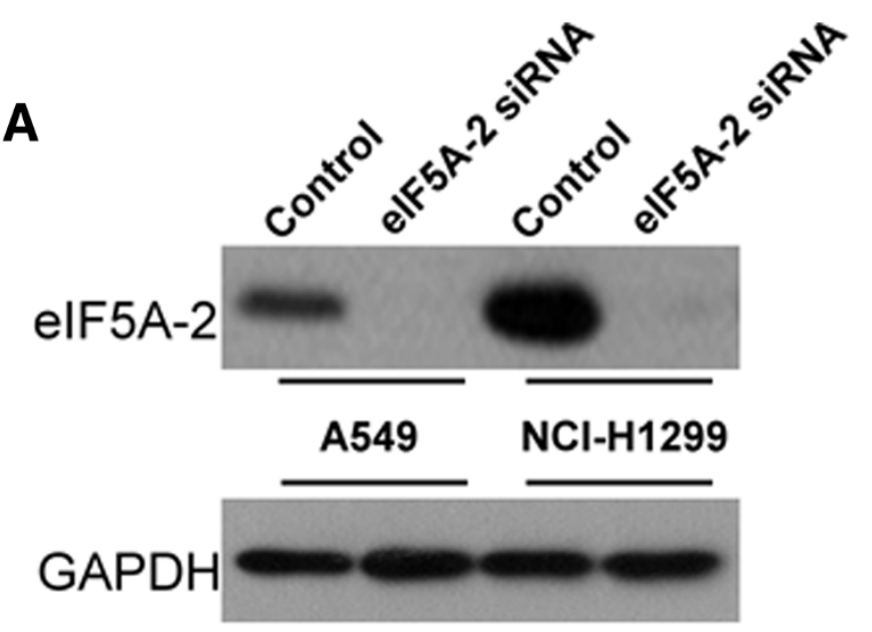

B

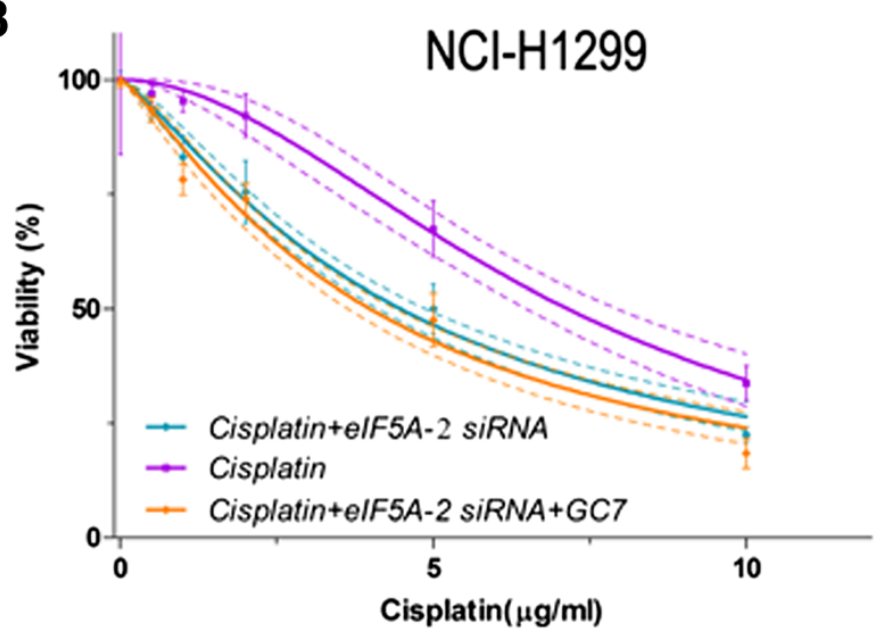

C

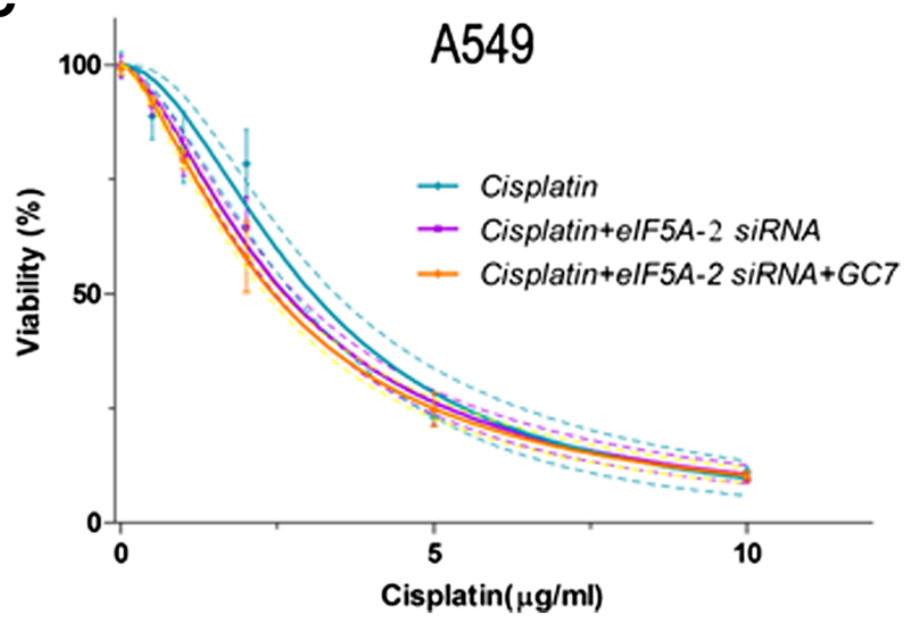

Figure 3 GC7 enhanced cisplatin sensitivity in NSCLC cells via inhibition of elF5A-2. (A) elF5A-2 siRNA inhibits elF5A-2 in both A549 and NCl-H1299 cells. (B-C) Comparing changes in cisplatin sensitivity in A549 and NCl-H1299 NSCLC cells after treatment with elF5A-2 siRNA alone or combined with GC7. 
GC7 enhanced cisplatin sensitivity, we transfected eIF5A-2 siRNA into A549 and NCI-H1299 cells to interfere with eIF5A-2 expression, and found that eIF5A-2 expression was significantly inhibited in both NSCLC cell lines (Figure 3A). We then treated these transfected cells with cisplatin alone, or cisplatin combined with GC7, and carried out CCK-8 cell viability assays. Without GC7, NCI-H1299 cells were the most sensitive to cisplatin after eIF5A-2 siRNA transfection: the $\mathrm{IC}_{50}$ at $72 \mathrm{~h}$ was $4.468 \mu \mathrm{g} / \mathrm{mL}$ (4.093-4.842 $\mu \mathrm{g} / \mathrm{mL}$; Table 2). Although A549 cells remained sensitive to cisplatin, the $\mathrm{IC}_{50}$ value was lower: $2.626 \mu \mathrm{g} / \mathrm{mL}(2.466-2.785 \mu \mathrm{g} / \mathrm{mL}$; $P=0.0145 v s$. cisplatin alone. Table 2). In contrast, when cisplatin treatment was combined with GC7 after eIF5A2 siRNA transfection, there was little change in the cisplatin sensitivity of both cell lines: the $\mathrm{IC}_{50}$ values at $72 \mathrm{~h}$ were $3.982 \mu \mathrm{g} / \mathrm{mL}(3.609-4.356 \mu \mathrm{g} / \mathrm{mL} ; P=0.0648)$ and $2.434 \mu \mathrm{g} / \mathrm{mL}(2.307-2.560 \mu \mathrm{g} / \mathrm{mL} ; P=0.0571)$ in NCI-H1299 and A549 cells, respectively (Table 2; Figure 3B,C). As GC7 also inhibits eIF5A-1's activity, we evaluated the role of eIF5A-1 in this process. Western Blot analysis indicated that eIF5A-1 was expressed in the control cells of both cell lines; however the expression of eIF5A-1 was higher in NCI-H1299 cells compared to A549 cells. Moreover, We also evaluated the effect of eIF5A-1 in the siRNA transfected cell. The results showed that when cisplatin treatment was combined with GC7 after eIF5A-1 siRNA transfection, there was little change in the cisplatin sensitivity of both cell lines (In Additional file 3).

\section{GC7 regulated EMT in NSCLC cells via inhibition of elF5A-2}

Having established that GC7 enhanced the chemotherapeutic effect of cisplatin in NCI-H1299 more than in A549 cells, we wished to determine whether the mechanism was related to EMT. After GC7 treatment for 72 h, A549 cells retained their epithelial characteristics (Figure 4A,B), whereas NCI-H1299 cells displayed a loss of mesenchymal properties and a gain of epithelial properties, appearing a reduction in their migration and invasion capabilities (Figure 4E,F). Furthermore, the NCI-H1299 cells showed increased levels of epithelial marker E-cadherin and lower levels of mesenchymal marker vimentin (Figure 4C,D).

Table 2 IC $_{50}$ values for cisplatin in NSCLC lines with or without GC7 treatment after elF5A-2 inhibition

\begin{tabular}{lll}
\hline $\begin{array}{l}\text { NSCLC } \\
\text { cell line }\end{array}$ & $\mathbf{I C}_{\mathbf{5 0}}(\boldsymbol{\mu g} / \mathbf{m L})$ & \\
\cline { 2 - 3 } & $\boldsymbol{s i R N A}+$ Cisplatin & siRNA + Cisplatin + GC7 (20 $\boldsymbol{\mu M})$ \\
\hline A549 & $2.626(2.466-2.785)$ & $2.434(2.307-2.560)$ \\
NCI-H1299 & $4.468(4.093-4.842)$ & $3.982(3.609-4.356)$ \\
\hline
\end{tabular}

${ }^{\Delta} \mathrm{IC}{ }_{50}$ values indicate the cisplatin concentration $[\mu \mathrm{g} / \mathrm{mL}$; mean $(95 \% \mathrm{Cl})]$.
Several reports have shown that TGF- $\beta 1$ could induce epithelial NSCLC cells to undergo EMT. In this study, TGF- $\beta 1$ exposure (10 ng/mL for $48 \mathrm{~h}$ ) transformed epithelial A549 cells to mesenchymal phenotype, causing the cells to develop an elongated appearance, irregular pseudopodia, weaker cell-cell junctions (Figure 5A) and stronger migration and invasion capabilities compared to control cells (Figure 5D,E). In addition, the cells showed lower levels of epithelial marker E-cadherin and increased levels of mesenchymal marker vimentin (Figure 5B,C). Conversely, if the A549 cells were pre-treated with GC7 before exposure to TGF- $\beta 1$, the cells retained their epithelial appearance, levels of EMT markers, and migration and invasion capabilities (Figure 5A-E).

In order to verify whether eIF5A-2 was a key factor in GC7 regulation of EMT, we transfected eIF5A-2 siRNA into NCI-H1299 cells without carrying out GC7 treatment. The results showed that the transfected NCIH1299 cells transformed from mesenchymal phenotype to epithelial phenotype (Figure 6A-D). Conversely, when the transfected cells were treated with GC7, the cells stayed as epithelial phenotype (Figure 6A-D).

\section{Discussion}

EIF5A-2 is a member of the eukaryotic initiation factor family. It is located on chromosome 3q26, a region frequently amplified in several tumors, and is highly expressed in tumors such as colorectal cancer [23], ovarian cancer [24] and bladder cancer [25]. Overexpression of eIF5A-2 has been reported to enhance invasion and metastasis in malignancies [20,26], for example, $\mathrm{He}$ et al. reported that overexpression of eIF5A-2 was correlated with invasion in NSCLC and was a poor prognostic marker of NSCLC [20]. In addition, eIF5A has been shown to induce EMT in hepatocellular carcinoma [26] and colorectal carcinoma [27].

Many studies have shown that EMT is related to carcinogenicity, metastasis and poor prognosis in many tumors including NSCLC [28-31], and it has been suggested that EMT is involved in drug resistance in NSCLC [10-12]. During EMT, epithelial markers such as E-cadherin decrease, while mesenchymal markers such as vimentin increase [8]. In our study, we showed that NCI-H1299 cells, a mesenchymal phenotype, expressed higher levels of eIF5A-2. In contrast A549 cells, an epithelial phenotype, expressed lower levels of eIF5A-2. Furthermore, we showed that epithelial A549 cells were more sensitive to cisplatin, whereas the mesenchymal NCIH1299 cells were related to drug resistance.

Several studies have reported that GC7 possesses antitumor properties [32,33] and significantly suppresses tumor cell proliferation $[21,22]$. The enzymes deoxyhypusine synthase (DHS) and deoxyhypusine hydroxylase (DOHH) are required to catalyze the post-translational modifications which lead to the activation of eIF5A2 [33]. GC7 is a 

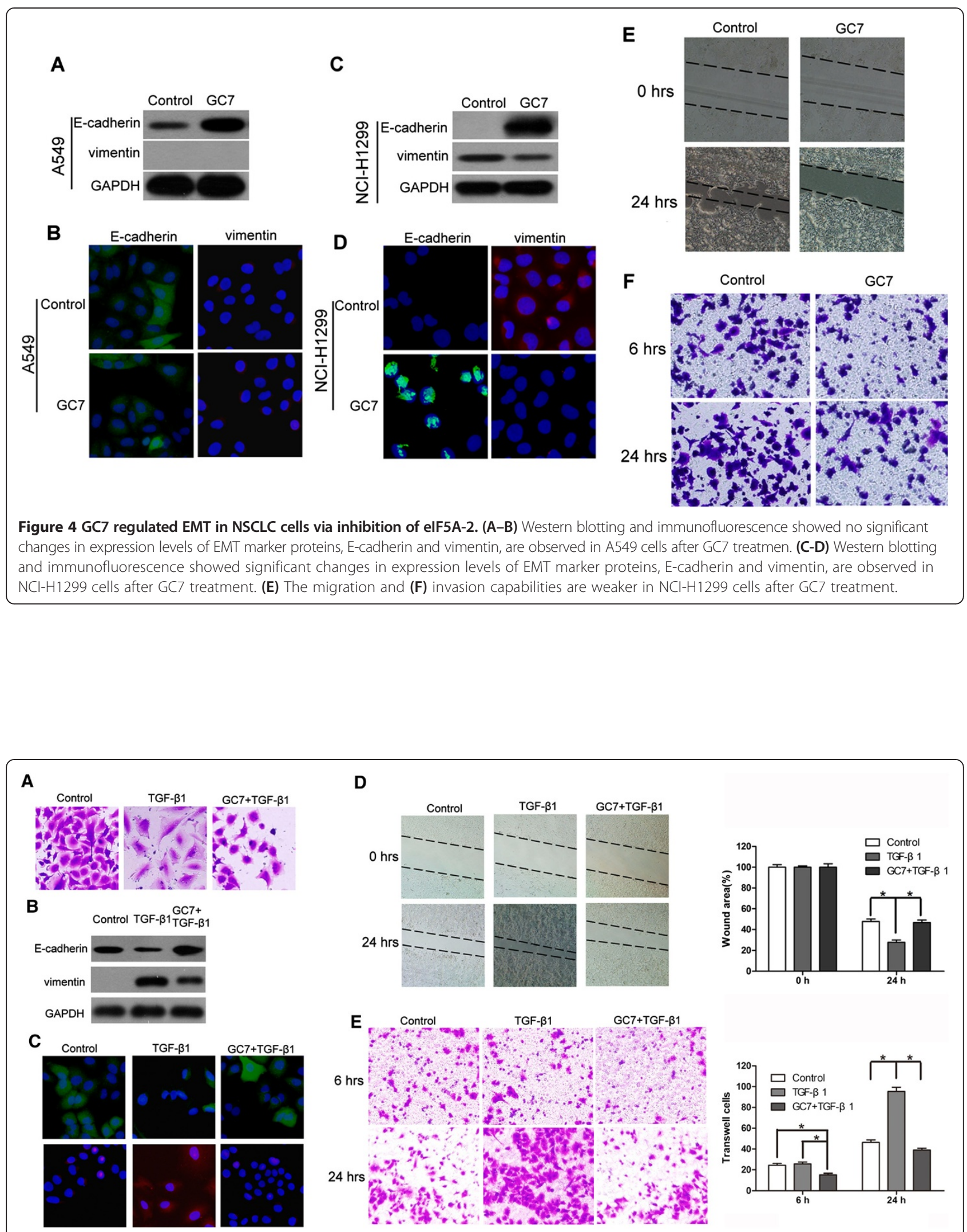

\section{D}
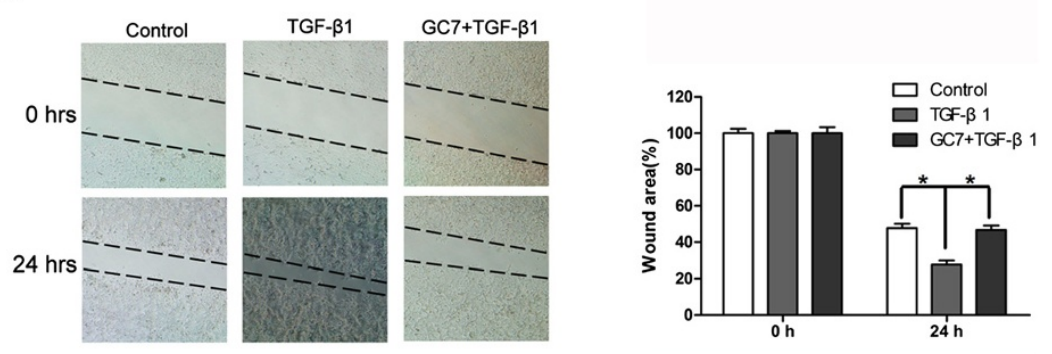

Figure 5 GC7 pre-treatment prevents A549 cells from undergoing EMT after TGF- $\beta 1$ stimulation. (A) morphology (B) Western blotting (C) immunofluorescence (D) wound-healing assay (E) Transwell-Matrigel invasion assay. 


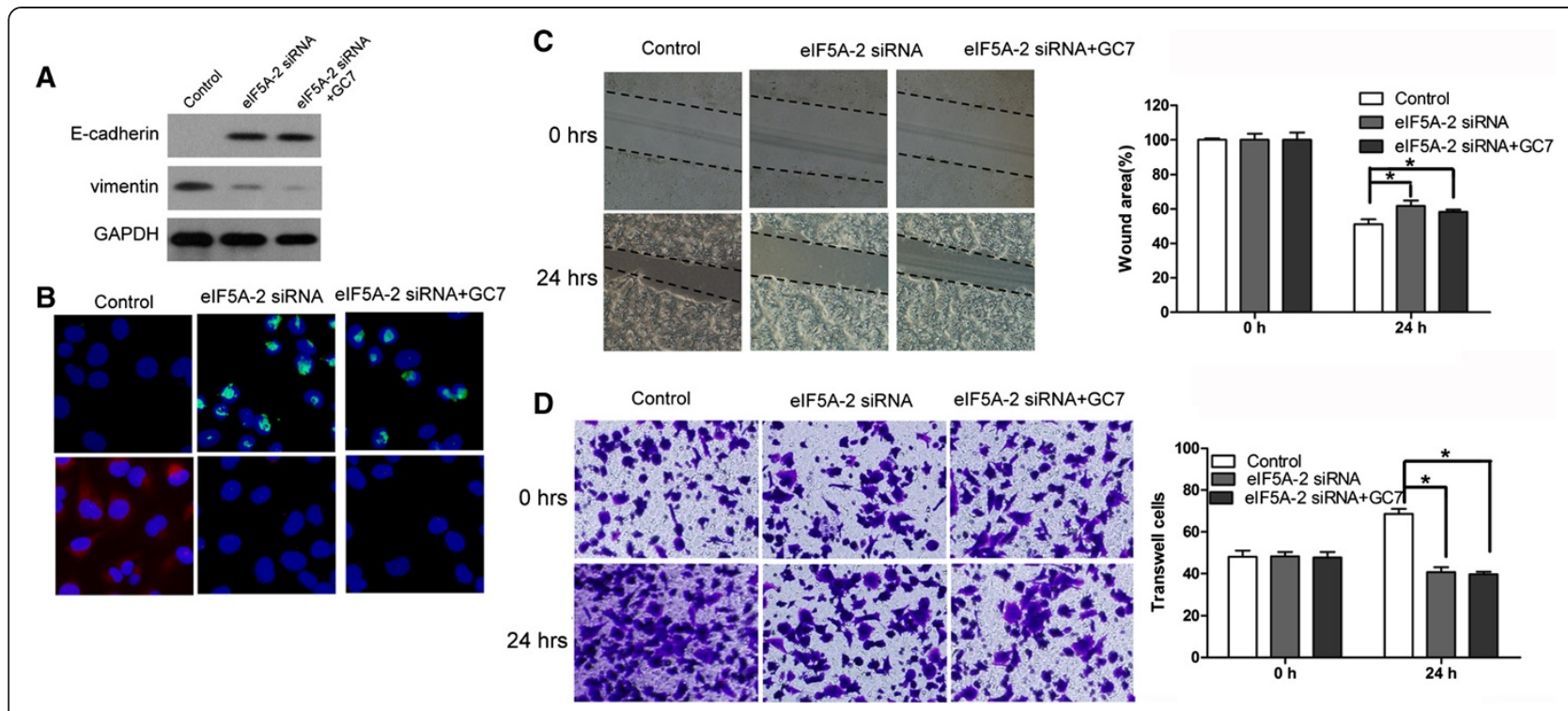

Figure 6 GC7 reverses EMT in NCl-H1299 cells via elF5A-2 regulation. (A) Western blotting (B) immunofluorescence (C) wound-healing assay (D) Transwell-Matrigel invasion assay.

potent inhibitor of DHS, thereby inducing eIF5A-2 inactivation. Our study found that mesenchymal NCI-H1299 cells changed to epithelial phenotype when co-treated with GC7; furthermore, in agreement with other reports, we found that GC7 not only increased NCI-H1299 sensitivity to cisplatin cells but also reduced the migration and invasion capabilities of NCI-H1299 cells.

TGF- $\beta$ signaling plays an important role in the EMT process through regulation of Snail, SOX2, SOX4 and ID1 [34-36] and has been reported to stimulate NSCLC cells to undergo EMT $[29,37,38]$. In previous study we found that after exposure to TGF- $\beta 1$, epithelial A549 cells changed to mesenchymal phenotype, developing a mesenchymal appearance, higher levels of vimentin, lower levels of E-cadherin and stronger migration and invasion capabilities [39]. In this study, we mainly investigate GC7 whether can be reversed this effect, and the result showed that EMT could be prevented if A549 cells were pre-treated with GC7. This suggested that eIF5A-2 might be an upstream factor regulating EMT and thereby plays an important role in EMT phenotype changes.

\section{Conclusion}

In conclusion, our study found that GC7 changed NCIH1299 cells from mesenchymal phenotype to epithelial phenotype and enhanced their sensitivity to cisplatin via inhibition of eIF5A-2, whereas GC7 prevented epithelial A549 cells from undergoing EMT changes via inhibition of eIF5A-2. This suggests that eIF5A-2 may be a key regulatory factor in EMT and drug resistance in NSCLC. As such, inhibition of eIF5A-2 could enhance NSCLC sensitivity to chemotherapeutics, prevent or reverse
EMT, and reduce the migration and invasion capabilities of NSCLC cells. These findings not only support the use of EIF5A2 as an adverse prognostic marker in NSCLC patients, but may also offer a novel approach for the treatment of NSCLC.

\section{Additional files}

Additional file 1: Figure S1. Evaluate the possible synergism between GC7 and cisplatin on the growth inhibition of NSCLC (A) NCI-H1299 (B) A549.

Additional file 2: Figure S2. Fluorogram of SDS-PAGE separated hypusinated-elF5A1/elF5A2 protein (Hypusined elF5A isoform) in NCI-H1299 and A549 cells protein lysates after $48 \mathrm{~h}$ incubation with or without GC7 $(20 \mu \mathrm{M})$ in the presence of $[1,8-3 \mathrm{H}]$-spermidine.

Additional file 3: Figure S3. (A-B) Comparing changes in cisplatin sensitivity in A549 and NCl-H1299 NSCLC cells after treatment with elF5A-1 siRNA alone or combined with GC7. (C) Western blotting showing elF5A-1 expression in A549 and NCl-1299 cells. (D) elF5A-1 siRNA inhibits elF5A-2 in both A549 and NCl-H1299 cells. (E) The effects of GC7 and cisplatin on the expression of the two isoforms of elF-5A in the NSCLC cell lines.

\section{Competing interests}

The authors declare that they have no competing interests.

\section{Authors' contributions}

GFS contributed to the conception and design of the study. GDX, QYZ and $\mathrm{NL}$ performed the statistical analysis and manuscript writing, LBS and DWZ performed the technical experiments. GDX and XBS participated in the design of the study and collected the clinical information. All the authors read and approved the final version of the manuscript.

\section{Acknowledgements}

This study was financially supported by grants from the Natural Science Fund of Ningbo (No. 2011A610052) and the Natural Science Fund of Zhejiang Province (No. LY12H16002). 


\section{Author details}

'Department of Thoracic \& Cardiovascular Surgery, Lihuili Hospital, Ningbo Medical Center, Affiliated Hospital of Medical School of Ningbo University, NO 57 Xingning Road, Ningbo 315041, China. '2Department of Pathology, Shanghai Pulmonary Hospital Tongji University School of Medical, Shanghai 200065, China. ${ }^{3}$ Department of Cell Biology and Medical Genetics, Research Center of Molecular Medicine, National Education Base for Basic Medical Sciences, Institute of Cell Biology, Zhejiang University School of Medicine, Hangzhou, Zhejiang Province 310058, China.

Received: 17 July 2013 Accepted: 16 October 2014

Published: 7 November 2014

\section{References}

1. Jemal A, Murray T, Samuels A, Ghafoor A, Ward E, Thun MJ: Cancer statistics, 2003. CA Cancer J Clin 2003, 53:5-26.

2. Schiller $\mathrm{JH}$, Harrington D, Belani $\mathrm{CP}$, Langer $\mathrm{C}$, Sandler A, Krook J, Zhu J, Johnson DH, Eastern Cooperative Oncology Group: Comparison of four chemotherapy regimens for advanced non-small-cell lung cancer. $N$ Engl J Med 2002, 346:92-98.

3. Ohe Y, Ohashi Y, Kubota K, Tamura T, Nakagawa K, Negoro S, Nishiwaki Y, Saijo N, Ariyoshi Y, Fukuoka M: Randomized phase III study of cisplatin plus irinotecan versus carboplatin plus paclitaxel, cisplatin plus gemcitabine, and cisplatin plus vinorelbine for advanced non-small-cell lung cancer: Four-Arm Cooperative Study in Japan. Ann Oncol 2007, 18:317-323.

4. Maemondo M, Inoue A, Kobayashi K, Sugawara S, Oizumi S, Isobe H, Gemma A, Harada M, Yoshizawa H, Kinoshita I, Fujita Y, Okinaga S, Hirano H, Yoshimori K, Harada T, Ogura T, Ando M, Miyazawa H, Tanaka T, Saijo Y, Hagiwara K, Morita S, Nukiwa T, North-East Japan Study Group: Gefitinib or chemotherapy for non-small-cell lung cancer with mutated EGFR. N Engl $J$ Med 2010, 362:2380-2388.

5. Thiery JP, Sleeman JP: Complex networks orchestrate epithelialmesenchymal transitions. Nat Rev Mol Cell Biol 2006, 7:131-142.

6. Xie D, Gore C, Liu J, Pong RC, Mason R, Hao G, Long M, Kabbani W, Yu L, Zhang $H$, Chen $H$, Sun X, Boothman DA, Min W, Hsieh JT: Role of DAB2IP in modulating epithelial-to-mesenchymal transition and prostate cancer metastasis. Proc Natl Acad Sci U S A 2010, 107:2485-2490.

7. Cao M, Seike M, Soeno C, Mizutani H, Kitamura K, Minegishi Y, Noro R, Yoshimura A, Cai L, Gemma A: MiR-23a regulates TGF- $\beta$-induced epithelial-mesenchymal transition by targeting $\mathrm{E}$-cadherin in lung cancer cells. Int J Oncol 2012, 41:869-875.

8. Thomson S, Petti F, Sujka-Kwok I, Mercado P, Bean J, Monaghan M, Seymour SL, Argast GM, Epstein DM, Haley JD: A systems view of epithelial-mesenchymal transition signaling states. Clin Exp Metastasis 2011, 28:137-155.

9. Sequist LV, Waltman BA, Dias-Santagata D, Digumarthy $S$, Turke AB, Fidias $P$, Bergethon K, Shaw AT, Gettinger S, Cosper AK, Akhavanfard S, Heist RS, Temel J, Christensen JG, Wain JC, Lynch TJ, Vernovsky K, Mark EJ, Lanuti M, lafrate AJ, Mino-Kenudson M, Engelman JA: Genotypic and histological evolution of lung cancers acquiring resistance to EGFR inhibitors. Sci Transl Med 2011, 3:75ra26.

10. Yauch RL, Januario T, Eberhard DA, Cavet G, Zhu W, Fu L, Pham TQ, Soriano $R$, Stinson J, Seshagiri S, Modrusan Z, Lin CY, O'Neill V, Amler LC: Epithelial versus mesenchymal phenotype determines in vitro sensitivity and predicts clinical activity of erlotinib in lung cancer patients. Clin Cancer Res 2005, 11:8686-8698.

11. Thomson S, Buck E, Petti F, Griffin G, Brown E, Ramnarine N, Iwata KK, Gibson N, Haley JD: Epithelial to mesenchymal transition is a determinant of sensitivity of non-small-cell lung carcinoma cell lines and xenografts to epidermal growth factor receptor inhibition. Cancer Res 2005, 65:9455-9462.

12. Rho JK, Choi YJ, Lee JK, Ryoo BY, Na II, Yang SH, Kim CH, Lee JC: Epithelial to mesenchymal transition derived from repeated exposure to gefitinib determines the sensitivity to EGFR inhibitors in A549, a non-small cell lung cancer cell line. Lung Cancer 2009, 63:219-226.

13. Caraglia M, Tagliaferri $P$, Budillon A, Abbruzzese A: Post-translational modifications of eukaryotic initiation factor-5A (elF-5A) as a new target for anti-cancer therapy. Adv Exp Med Biol 1999, 472:187-198.

14. Caraglia M, Park MH, Wolff EC, Marra M, Abbruzzese A: elF5A isoforms and cancer: two brothers for two functions? Amino Acids 2013, 44(1):103-109.
15. Guan XY, Sham JS, Tang TC, Fang Y, Huo KK, Yang JM: Isolation of a novel candidate oncogene within a frequently amplified region at 3q26 in ovarian cancer. Cancer Res 2001, 61:3806-3809.

16. Clement PM, Henderson CA, Jenkins ZA, Smit-McBride Z, Wolff EC, Hershey JW, Park MH, Johansson HE: Identification and characterization of eukaryotic initiation factor 5A-2. Eur J Biochem 2003, 270:4254-4263.

17. Clement PM, Johansson HE, Wolff EC, Park MH: Differential expression of elF5A-1 and elF5A-2 in human cancer cells. FEBS J 2006, 273:1102-1114.

18. Clement PM, Hanauske-Abel HM, Wolff EC, Kleinman HK, Park MH: The antifungal drug ciclopirox inhibits deoxyhypusine and proline hydroxylation, endothelial cell growth and angiogenesis in vitro. Int J Cancer 2002, 100:491-498.

19. Nishimura K, Murozumi K, Shirahata A, Park MH, Kashiwagi K, Igarashi K: Independent roles of elF5A and polyamines in cell proliferation. Biochem J 2005, 385:779-785.

20. He LR, Zhao HY, Li BK, Liu YH, Liu MZ, Guan XY, Bian XW, Zeng YX, Xie D: Overexpression of elF5A-2 is an adverse prognostic marker of survival in stage I non-small cell lung cancer patients. Int J Cancer 2011, 129:143-150.

21. Lee Y, Kim HK, Park HE, Park MH, Joe YA: Effect of N1-guanyl-1,7-diaminoheptane, an inhibitor of deoxyhypusine synthase, on endothelial cell growth, differentiation and apoptosis. Mol Cell Biochem 2002, 237:69-76.

22. Wolff EC, Kang KR, Kim YS, Park MH: Posttranslational synthesis of hypusine: evolutionary progression and specificity of the hypusine modification. Amino Acids 2007, 33:341-350.

23. Xie D, Ma NF, Pan ZZ, Wu HX, Liu YD, Wu GQ, Kung HF, Guan XY: Overexpression of EIF-5A2 is associated with metastasis of human colorectal carcinoma. Hum Pathol 2008, 39:80-86.

24. Yang GF, Xie D, Liu JH, Luo JH, Li LJ, Hua WF, Wu HM, Kung HF, Zeng YX, Guan XY: Expression and amplification of elF-5A2 in human epithelial ovarian tumors and overexpression of EIF-5A2 is a new independent predictor of outcome in patients with ovarian carcinoma. Gynecol Oncol 2009, 112:314-318

25. Chen W, Luo JH, Hua WF, Zhou FJ, Lin MC, Kung HF, Zeng YX, Guan XY, Xie D: Overexpression of EIF-5A2 is an independent predictor of outcome in patients of urothelial carcinoma of the bladder treated with radical cystectomy. Cancer Epidemiol Biomarkers Prev 2009, 18:400-408.

26. Tang DJ, Dong SS, Ma NF, Xie D, Chen L, Fu L, Lau SH, Li Y, Li Y, Guan XY: Overexpression of eukaryotic initiation factor $5 \mathrm{~A} 2$ enhances cell motility and promotes tumor metastasis in hepatocellular carcinoma. Hepatology 2010, 51:1255-1263.

27. Zhu W, Cai MY, Tong ZT, Dong SS, Mai SJ, Liao YJ, Bian XW, Lin MC, Kung $H F$, Zeng $Y X$, Guan XY, Xie D: Overexpression of EIF5A2 promotes colorectal carcinoma cell aggressiveness by upregulating MTA1 through C-myc to induce epithelial-mesenchymal transition. Gut 2012, 61:562-575.

28. Singh A, Greninger P, Rhodes D, Koopman L, Violette S, Bardeesy N, Settleman J: A gene expression signature associated with "K-Ras addiction" reveals regulators of EMT and tumor cell survival. Cancer Cell 2009, 15:489-500.

29. Saito RA, Watabe T, Horiguchi K, Kohyama T, Saitoh M, Nagase T, Miyazono $\mathrm{K}$ : Thyroid transcription factor- 1 inhibits transforming growth factor-beta-mediated epithelial-to-mesenchymal transition in lung adenocarcinoma cells. Cancer Res 2009, 69:2783-2791.

30. Soltermann A, Tischler V, Arbogast S, Braun J, Probst-Hensch N, Weder W, Moch H, Kristiansen G: Prognostic significance of epithelial-mesenchymal and mesenchymal-epithelial transition protein expression in non-small cell lung cancer. Clin Cancer Res 2008, 14:7430-7437.

31. Thiery JP: Epithelial-mesenchymal transitions in tumour progression Nat Rev Cancer 2002, 2:442-454.

32. Shi XP, Yin KC, Ahern J, Davis L, Stern AM, Waxman L: Effects of N1guanyl-1,7-diaminoheptane, an inhibitor of deoxyhypusine synthase, on the growth of tumorigenic cell lines in culture. Biochim Biophys Acta 1996, 1310:119-126

33. Jasiulionis MG, Luchessi AD, Moreira AG, Souza PP, Suenaga AP, Correa M, Costa CA, Curi R, Costa-Neto CM: Inhibition of eukaryotic translation initiation factor $5 \mathrm{~A}$ (elF5A) hypusination impairs melanoma growth. Cell Biochem Funct 2007, 25:109-114.

34. Thiery JP, Acloque H, Huang RY, Nieto MA: Epithelial-mesenchymal transitions in development and disease. Cell 2009, 139:871-890.

35. Chen XF, Zhang HJ, Wang HB, Zhu J, Zhou WY, Zhang H, Zhao MC, Su JM, Gao W, Zhang L, Fei K, Zhang HT, Wang HY: Transforming growth factor- $\beta 1$ induces epithelial-to-mesenchymal transition in human lung cancer cells 
via PI3K/Akt and MEK/Erk1/2 signaling pathways. Mol Biol Rep 2012, 39:3549-3556.

36. Zhang $H J$, Wang HY, Zhang HT, Su JM, Zhu J, Wang HB, Zhou WY, Zhang $H$, Zhao MC, Zhang L, Chen XF: Transforming growth factor- $\beta 1$ promotes lung adenocarcinoma invasion and metastasis by epithelial-to-mesenchymal transition. Mol Cell Biochem 2011, 355:309-314.

37. Kasai H, Allen JT, Mason RM, Kamimura T, Zhang Z: TGF-beta1 induces human alveolar epithelial to mesenchymal cell transition (ET). Respir Res 2005, 6:56.

38. Kim JH, Jang YS, Eom KS, Hwang Yl, Kang HR, Jang SH, Kim CH, Park YB, Lee $M G$, Hyun IG, Jung KS, Kim DG: Transforming growth factor beta1 induces epithelial-to-mesenchymal transition of A549 cells.J Korean Med Sci 2007, 22:898-904.

39. Xu GD, Shi XB, Sun LB, Zhou QY, Zheng DW, Shi HS, Che YL, Wang ZS, Shao GF: Down-regulation of elF5A-2 prevents epithelial-mesenchymal transition in non-small-cell lung cancer cells. J Zhejiang Univ Sci B 2013, 14:460-467.

doi:10.1186/1471-2466-14-174

Cite this article as: Xu et al:: Cisplatin sensitivity is enhanced in non-small cell lung cancer cells by regulating epithelial-mesenchymal transition through inhibition of eukaryotic translation initiation factor 5A2. BMC Pulmonary Medicine 2014 14:174.

\section{Submit your next manuscript to BioMed Central and take full advantage of:}

- Convenient online submission

- Thorough peer review

- No space constraints or color figure charges

- Immediate publication on acceptance

- Inclusion in PubMed, CAS, Scopus and Google Scholar

- Research which is freely available for redistribution 